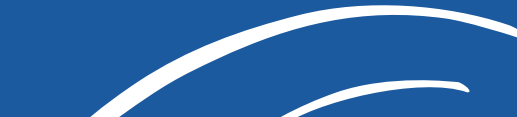 \\ AGUA Y TERRITORIO
}

\section{Una lectura histórica del mapa de Azcapotzaltongo de 1578}

\author{
A Historical Reading of the 1578 Map of Azcapotzaltongo \\ Teresa Rojas-Rabiela
}

Centro de Investigaciones y Estudios Superiores en Antropología Social. México D.F., México. chepinina@hotmail.com

Resumen - El artículo presenta los resultados de un estudio sobre el Mapa-códice de Azcapotzaltongo, espacio situado en la cuenca del río Cuautitlán, modificado desde la época prehispánica para dar paso a un sistema de riego de grandes dimensiones. El objetivo es mostrar las posibilidades que tiene este tipo de documentos para conocer las características del espacio registrado y, a partir de este análisis, estudiar los procesos de cambio y continuidad en el paisaje. Los tres asentamientos indios que se documentan están ubicados al norte de la cuenca de México, cerca de la ciudad de México y se caracterizan por mostrar el avance de la apropiación del suelo por varios españoles, la presencia de la ganadería mayor y menor y del cultivo de trigo de riego, así como de algunas otras plantas introducidas por los españoles. La lectura que propongo se basa en la observación y registro detallado de los espacios, glifos y dibujos, antecedido por la ruta marcada por las diligencias a cargo de las autoridades reales, hecho con el auxilio de una guía numérica. Se trata de deconstruir el mapa, es decir, de descomponerlo en unidades con sentido, que permitan entender mejor sus significados tanto particulares como del conjunto.

Abstract - This article presents the results of a study about the 1578 Map-codex of Azcapotzaltongo, a space situated in the basin of the Cuautitlán river whose pre-Hispanic course had been altered to make way for a large irrigation system. Our goal is to show the potential that this type of document offers to understand the features of the highlighted area and, starting from this analysis, study the processes of change and continuity in the landscape. The three Indian settlements shown on the map are located to the north of the Cuenca de Mexico (Basin of Mexico), near the city of Mexico and reveal the spreading appropriation of land by several Spanish colonists, the presence of livestock activity, and the cultivation of irrigated wheat and other plants introduced by the Spaniards.

The reading that I propose, which will be preceded by an examination of the administrative steps followed by the royal authorities that commissioned the map, is based on the observation and detailed analysis of the documented spaces, glyphs and drawings accomplished with the help of a numerical guide. The map is broken down into discreet units to allow us to better understand the meanings of both its individual parts and the entire represented image as a whole.

\begin{abstract}
Palabras clave: Cuenca de México; irrigación; Río Cuatitlán; mapa-códice; paisaje; pueblos de indios Keywords: Basin of Mexico; irrigation; Cuatitlán river; map-codex; landscape; indigenous towns
\end{abstract}

Información Artículo: Recibido: 24 mayo 2014

Revisado: 15 julio 2014

Aceptado: 23 septiembre 2014

๔ Universidad de Jaén / Seminario Permanente Agua, Territorio y Medio Ambiente (CSIC) 